\title{
Comparative Study on Internal Principal-Agent Structure between REITs and Similar Investment Instruments
}

\author{
Li Haijia $^{1}$, He Chunming ${ }^{2}$ \\ ${ }^{1 .}$ Business School of Sichuan University \\ 2. Jincheng School of Sichuan University
}

Keywords: REITs; collective investment instruments; principal-agent structure; internal governance structure

Abstract: In China, it is an inevitable trend to develop local REITs and study how to distinguish it from similar investment instruments, so the analysis on the internal governance structure of REITs will be of great practical significance. By comparing REITs with 4 other collective investment instruments, this paper delves into the characteristics of basic internal governance structure, which differ REITs from other collective investment instruments, and provides beneficial reference for REITs developed in China.

\section{Introduction}

Real estate investment trusts (REITs) are a kind of trust funds or special companies that raise the fund from investors by issuing shares or beneficiary certificates, entrust professional investment institutions with the operation and management of invested real estate, and distribute the earnings to investors in proportion to their contribution. REITs can be classified into Group REITs and corporate REITs. The basic organizational structure of Group REITs is a trust fund, while corporate REITs are organized on the basis of company. Moreover, REITs can be also classified into equity and mortgage REITs due to different types of investment. Equity REITs invest in real estate projects, obtain the ownership and get their benefits through long-term operation and management; and mortgage REITs mainly make investments in real estate mortgage loans or real estate backed securities. Group equity REITs are the basic and mainstream type of REITs in the world, so the REITs mentioned in this paper refer to this kind, and their basic organizational structure is as presented in the following figure 1:

The real estate market in China has experienced the rapid development for two decades, and has now started the transformation from the stage of incremental and high-speed circulation to the stage of stock property operation optimization. The overwhelming stock of real estate has nurtured the strong request for the development of China's local REITs in the market. As revealed in the relevant statistical data, the stock of retail business properties and office buildings in main cities of China has reached to 110 million square meters; the real estate market has a scale of up to USD44 trillion; and the market value of REITs will reach to USD1.67 trillion, which is much higher than the sum of the REITs in the whole Asian market, and even not much lower than the REIT market in the United States. To identify the internal governance characteristics of REITs, this paper studies and compares the internal principal-agent structure of REITs with that of 4 other investment instruments, i.e., 
securities investment fund, private equity investment fund, ordinary real estate trust, asset-backed securities (ABS). After analyzing the principal-agent relationships between investors and investment manager and between investment manager and underlying asset management institutions, this paper will delve into the characteristics of REITs' principal-agent structure compared with that of other investment instruments.

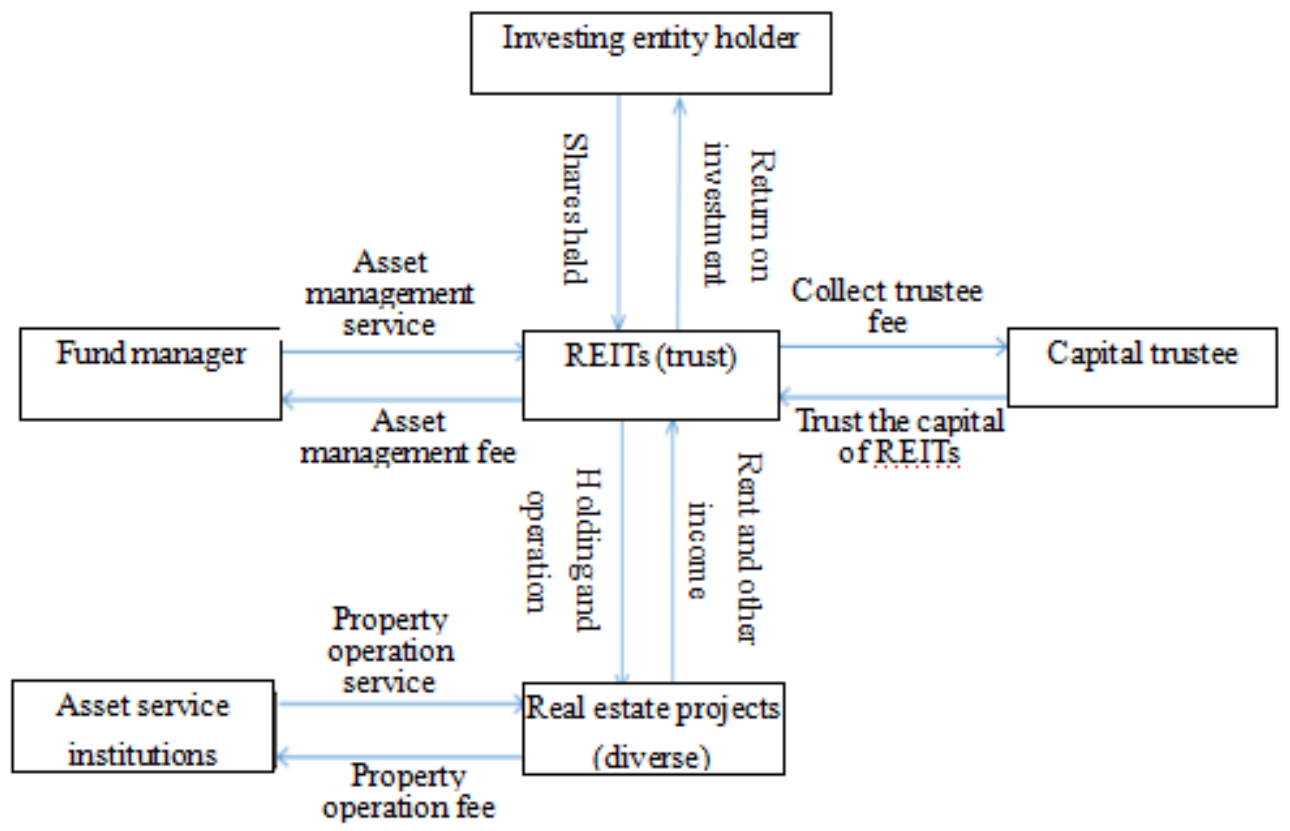

Fig.1 Basic organizational structure

\section{Internal Principal-Agent Structure between REITs and Similar Collective Investment Instruments}

\subsection{REITs}

This paper studies the relationships among investors, fund manager and asset service institutions in REITs, as the relationships are crucial to the internal governance of REITs. In REITs, fund manager basically provides financial services, that is, gather the capital from investors, select and invest in the high-quality real estate that can be operated to produce income constantly. The properties held by REITs should be still operated by professional and experienced real estate management institutions, that is, "property management service institutions" mentioned in this paper, which are actually responsible for operating the properties held by REITs. Therefore, there are obviously two levels of principal-agent relationship in REITs. The first level is the relationship between fund manager and investors. The second level is the relationship between asset management service institutions and fund manager.

\subsection{Equity Securities Investment Fund}

Securities investment fund creates the principal-agent relationship between investors and fund manager in other words, an investor can purchase shares of securities investment fund to entrust the fund manager with the management of own capital, in order to gain benefits while bearing risks. However, equity securities investment fund invests in the equity of listed companies, so the fund purchases shares of listed companies and then forms a "shareholder-management" relationship with the management level of an invested company. In this relationship, fund manager exercises the 
rights on behalf of the fund. Therefore, equity securities investment fund has a two-level principal-agent structure.

\subsection{Private Equity Investment Fund}

The observation reveals that there is also the "two-level principal-agent" relationship in private equity investment fund. On one hand, capital is entrusted by investors to fund manager, and then invested by fund manager into entities as a shareholder, which invests the capital into the management level of an entity. On the other hand, the value of private equity investment fund can be enhanced through the operation and development of the invested entities. This operation mode of private equity investment fund will also generate a two-level principal-agent relationship.

\subsection{Ordinary Real Estate Trust}

Ordinary real estate trust is an indirect mode of financing real estate development projects. Due to its complicated operation process and multiple parties involved, there may be several levels of principal-agent relationship in ordinary real estate trust. Liu (2007) simplified these levels into two levels for real estate trusts in China considering the relationships among parties involved in real estate trusts. The first level is the relationship between investors (principal) and trust investment company (agent). The second level of relationship exists between trust investment company (fund manager) as the principal, and several other parties entrusted by fund manager, e.g. banks, real estate development companies, investment consulting companies and securities companies, so it can be directly regarded as the principal-agent relationship between trust investment company (principal) and other parties (agent). However, it is believed that the second level proposed by Liu has a defect, that is, the relationship between trust investment company, i.e. investment manager, and actual user of trusted capital (real estate developers), is a creditor-debtor relationship, instead of "principal-agent relationship", for it's obvious that real estate developers bear the main risks and benefits in this finance independently, but the trust investment company is only responsible for the risk of loan and enjoys the benefit from interests. Hence, there is only a single-level principal-agent relationship in ordinary real estate trusts.

\subsection{Asset-backed Securities (ABS)}

The principal-agent theory describes a transactional relationship under the conditions of information asymmetry. Normally, a principal purchases the management and service from an agent, while the agent is responsible for practical management and service. For this reason, ABS also has a unique principal-agent relationship. The analysis on the structure of principal-agent relationship in ABS mainly focuses on investors and trust institution holding the underlying assets of ABS. The trust institution is the ABS investment manager. Nevertheless, ABS is an investment instrument involving creditor's rights, so there is the creditor-debtor relationship between investment manager and underlying asset manager, instead of principal-agent relationship. In other words, there is only a single-level principal-agent relationship in ABS.

\section{Comparison of Collective Investment Instruments with a Two-level Principal-agent Structure}

As revealed in the above analysis on the principal-agent structure of Group REITs, securities investment fund, private equity investment fund, ordinary real estate trust and asset-backed securities (ABS), the first three instruments have a double-level principal-agent structure of 
"investors $\rightarrow$ investment manager $\rightarrow$ underlying asset manager", while a single-level principal-agent structure exists in ordinary real estate trust and ABS, i.e. "investors $\rightarrow$ investment manager", which is actually similar in all these collective investment instruments. In the relationship between investors and investment manager, investors have to entrust a professional institution with the management of their capital by entering into a contract due to their own limitations, and will gain benefits and bear risks according to the terms and conditions of the contract and the shares they purchase. Nevertheless, the relationship between investment manager and underlying asset manager varies significantly in Group REITs, securities investment fund and private equity investment fund. This paper will particularly address several aspects of this relationship, i.e. continuity of principal-agent relationship, influence of principal on agent, whether principal managers the underlying assets voluntarily, and whether the agent's performance is easily observed.

\subsection{Continuity of Principal-agent Relationship}

The underlying assets of securities investment fund are the standard securities tradable in the market, so they are featured by good liquidity and high turnover rate. For this reason, the principal-agent relationship does not last between the equity securities investment fund manager and the management level of invested listed companies. However, real estate, as the underlying asset of Group REITs, and equity of unlisted companies, as the underlying asset of private equity investment fund, are both the assets with poor liquidity, and cannot generate the profits through frequent transactions from the perspective of return on investment. In this case, the principal-agent relationship, i.e. relationship between investment manager and underlying asset manager, continues in both Group REITs and private equity investment fund.

\subsection{Whether Principal Managers do active management to the Underlying Assets}

As there is not a continuous principal-agent relationship between investment manager and underlying asset manager, a fund manager of securities investment fund normally does not directly interfere with the operation and management of invested companies. When the fund manager does not satisfy with the operation and management of invested companies due to poor liquidity of the underlying assets, he may directly sell the equity of invested companies to avoid any adverse effects. Meanwhile, the underlying assets of Group REITs and private equity investment fund have poor liquidity, but their principal-agent relationship between investment manager and underlying asset manager is lasting. In a private equity investment fund, fund manager normally takes an active part in the management of a target enterprise as a shareholder after making an investment in the enterprise, and provides a series of supporting and consulting services for the management of the enterprise, so as to facilitate the increase in the value of the enterprise and enjoy the benefits from it. Fund manager in Group REITs controls the assets held by REITs on behalf of investors, and assumes the direct responsibility for the management and operation efficiency of assets. The fund manager may employ a professional property management and operation institution on behalf of investors to provide professional services, but must make decisions on some important issues, e.g. purchase and sale, upgrading and renovation, and change of use of assets. In other words, fund manager of REITs must take part in the management of the underlying assets.

\subsection{Whether the Agent's Performance is Easily Observed}

It is clear that the underlying asset of equity securities investment fund is the equity of listed companies, so the condition and performance of asset operation should be disclosed according to laws, and stock price is closely related to the operation of company. For this reason, it is easy to 
observe the performance of agent in the principal-agent relationship between investment manager and underlying asset manager. However, the underlying asset of private equity investment fund is the equity of unlisted companies, which also provide all kinds of financial statements and information on major operations to the fund, so the performance of agent in its principal-agent relationship between investment manager and underlying asset manager can be easily and directly observed. Differently, REITs often involve multiple underlying assets, which may be in different trades and regions, and whose operation is not only directly related to the work performance of asset service institutions, but also significantly affected by the fluctuation of local real estate market. For this reason, it is difficult to directly observe or horizontally compare the performance in the operation of assets owned by REITs, and it is not easy to directly observe the performance of agent in its principal-agent relationship between investment manager and underlying asset manager.

\section{Conclusion}

Above all, there is the two-level principal-agent relationship of "investors $\rightarrow$ fund manager $\rightarrow$ underlying asset manager" in REITs, and its level of relationship between investment manager and underlying asset manager is much different from that in other collective investment instruments. First, there is a long-term and continuous principal-agent relationship between fund manager and asset management service institutions in REITs. Second, fund manager of REITs must take part in the disposal management of property projects. Third, the performance of asset management service institutions in REITs is highly affected by environmental factors, so it is difficult to directly observe or horizontally compare it with others.

Additionally, there is a "one-to-many" principal-agent relationship between fund manager and asset management service institutions in REITs, so the study on its principal-agent relationship must involve the horizontal comparison of agents, but it is not detailed in this paper due to limited space. However, the study will be certainly further carried out along with the development of local REITs in China.

\section{References}

[1] Ge Feng. Whether REITs is suitable for China? [J]. China Economic Weekly, 2015 (18), 2-2.

[2] Chen Sicong. Comparative Research on Real Estate Investment Trust System between China and the United States

[D]. Shanghai Jiaotong University, 2015.

[3] Liu Jinchuan. Study on Moral Risk of Economics Respect in Real Estate Trust--Based on the View of Investor [D]. Chongqing University, 2007.

[4] Liu Yuanhua. Analysis on principal-agent relationship in securities investment fund from the view of game [J]. Financial Theory \& Practice, 2008 (6): 84-85.

[5] Yin Yongli. Research on the Dual Principal-Agent Problem of Private Equity Fund [D]. Southwestern University of Finance and Economics, 2012.

[6] Zhang Lei, Jia Jinping. Study on the governance mechanism for two-level principal-agent risk in private equity funds. Modern Property Management, 2009 (11):26-27+50.

[7] Berman, Andrew, Suresh, Wick. Does stakeholder Orientation Matter? The Relationship between stakeholder management Models and Firm Financial Peformance[J]. Academy of Management Journa1, 1999(42):488 - 506.

[8] Brent W. Ambrose and Peter Linneman. RE1T Organization Structure and Operating Characteristics[J]. Journal ofReal Estate Research, 2001,21(3):141 - 162

[9] Chinmoy Ghosh, C.F.Sirmans. Board Independence, Ownership Structure and Performance: Evidence from Real Estate Investment Trusts[J]. Journal of Real Estate Finance and Economics, 2003: 287-318. 